\title{
How Is Endoscopic Submucosal Dissection for Gastrointestinal Lesions Being Implemented? Results from an International Survey
}

\author{
Miguel Araújo-Martins ${ }^{c}$ Pedro Pimentel-Nunes ${ }^{\mathrm{a}-\mathrm{c}}$ Diogo Libânio ${ }^{\mathrm{a}, \mathrm{b}}$ \\ Marta Borges-Canhac Mário Dinis-Ribeiro ${ }^{a, b}$ \\ ${ }^{a}$ Department of Gastroenterology, Portuguese Oncology Institute of Porto, Porto, Portugal; ${ }^{b}$ Center for Research in \\ Health Technologies and Information Systems (CINTESIS), Faculty of Medicine, University of Porto, Porto, Portugal; \\ ${ }^{C}$ Department of Surgery and Physiology, Faculty of Medicine, University of Porto, Porto, Portugal
}

\section{Keywords}

Endoscopic submucosal dissection · Survey ·

Gastrointestinal superficial lesions

\section{Abstract}

Background and Study Aim: Superficial gastrointestinal (Gl) neoplasms can be treated with endoscopic mucosal resection (EMR) and/or endoscopic submucosal dissection (ESD). These techniques are widely used in Eastern countries; however, its use in the West is limited. The aim of this study was to evaluate the current implementation of ESD in Western countries. Methods: Western endoscopists $(n=279)$ who published papers related to EMR/ESD between 2005 and 2017 were asked to complete an online survey from December 2017 to February 2018. Results: A total of 58 endoscopists (21\%) completed the survey. Thirty performed ESD in the esophagus (52\%), 45 in the stomach (78\%), 36 in the colorectum (62\%), and 6 in the duodenum (10\%). The median total number of lesions ever treated per endoscopist was 190, with a median number per endoscopist in 2016 of 41 (7 [IQR 1-21], 6 [IQR 4-16], and 28 [5-63] in the esophagus, in the stomach, and in the colon and rectum, respectively). En bloc resection rates were $97 \%$ in the esophagus, $95 \%$ in the stomach, and $84 \%$ in the colorectum. Complete resection
(R0) was achieved in 88,91 , and $81 \%$, respectively. Curative rates were 69,70 , and $67 \%$, respectively. Major complications (perforation or delayed bleeding) occurred more often in colorectal ESD (12 vs. $6 \%$ in the esophagus and $7 \%$ in the stomach). In the upper Gl tract, the majority of resected lesions were intramucosal adenocarcinoma (59\% in the esophagus; $47 \%$ in the stomach), while in the colorectum the majority were adenomas (59\%). Conclusion: ESD seems to be performed by a large number of centers and endoscopists. Our results suggest that ESD is being successfully implemented in Western countries, achieving a good rate of efficacy and safety according to European guidelines.

\footnotetext{
(c) 2019 Sociedade Portuguesa de Gastrenterologia Published by S. Karger AG, Basel
}

\section{Como é que a disseção endoscópica da submucosa está a ser implementada no tratamento de lesões gastrointestinais? Resultados de um questionário internacional}

\section{Palavras chave}

Disseção endoscópica da submucosa · Questionário · Lesões superficiais gastrointestinais

\section{KARGER}

E-Mail karger@karger.com www.karger.com/pjg
(C) 2019 Sociedade Portuguesa de Gastrenterologia Published by S. Karger AG, Basel

Karcer

Open access

This article is licensed under the Creative Commons AttributionNonCommercial-NoDerivatives 4.0 International License (CC BYNC-ND) (http://www.karger.com/Services/OpenAccessLicense). Usage and distribution for commercial purposes as well as any distribution of modified material requires written permission.
Pedro Pimentel-Nunes

Department of Gastroenterology, Portuguese Oncology Institute of Porto Rua Dr. Bernardino de Almeida

PT-4200-072 Porto (Portugal)

E-Mail pedronunesml@gmail.com 


\section{Resumo}

Introdução e objetivos: As lesões superficiais gastrointestinais podem ser tratadas por musectomia (EMR) e/ou disseção endoscópica da submucosa (ESD). Estas técnicas são usadas frequentemente nos países asiáticos, mas a experiência é mais limitada nos países ocidentais. O objetivo deste estudo foi avaliar a implementação atual da ESD nos países ocidentais. Métodos: Gastroenterologistas ocidentais ( $n=279$ ) com artigos publicados entre 2005 e 2017 relacionados com EMR/ESD foram solicitados a preencher um questionário online, no período de Dezembro 2017 até Fevereiro 2018. Resultados: Um total de 58 gastroenterologistas (21\%) completou o inquérito. Trinta realizaram ESD esofágica (52\%); 45 gástrica (78\%); 36 coloretal (62\%); e 6 duodenal (10\%). A mediana do número total de lesões ressecadas por endoscopista foi 190, sendo que, em 2016, a mediana de lesões tratadas por cada gastroenterologista foi 41 (7 [IQR 1-21] no esófago, 6 [IQR 4-16] no estômago e 28 [5-63] no cólon e reto). A taxa de ressecção em bloco foi de $97 \%$ nas lesões esofágicas; $95 \%$ nas lesões gástricas e $84 \%$ nas lesões coloretais, com uma proporção de casos $\mathrm{R} 0$ de 88,91 e $81 \%$, respetivamente. A taxa de casos curados foi de 69,70 e $67 \%$, respetivamente. A taxa de complicações graves (perfuração e hemorragia tardia) foi maior na ESD coloretal ( $12 \%$ dos casos vs. $6 \%$ no esófago e $7 \%$ no estômago). A maioria das lesões esofagogástricas eram adenocarcinomas intramucosos (59\% no esófago; $47 \%$ no estômago), enquanto as lesões coloretais eram maioritariamente adenomas (59\%). Conclusões: Este estudo mostra uma disseminação da ESD na europa por um maior número de centros e gastrenterologistas. Os nossos resultados sugerem uma utilização e eficácia global de acordo com as recomendações europeias.

(c) 2019 Sociedade Portuguesa de Gastrenterologia Publicado por S. Karger AG, Basel

\section{Introduction}

Superficial gastrointestinal (GI) neoplastic lesions with minimal risk of lymph node metastasis can be treated with minimally invasive endoscopic procedures, namely with endoscopic mucosal resection (EMR) and endoscopic submucosal dissection (ESD) [1].

EMR was first described in Japan in the early 1990s, and it is suitable for treating a majority of superficial esophageal and colorectal lesions [1]. Still, if lesions are larger than $15-20 \mathrm{~mm}$ or non-lifting, it is generally not possible to remove them en bloc, possibly leading to high local recurrence rates [2]. ESD was developed years later to pro- vide en bloc R0 resections regardless of the size of tumor and a more precise histopathological assessment, even though it is considered technically more difficult to perform and associated with a higher complication rate [2-4].

Although ESD is widely used in Eastern countries, its use in the West is limited, and in some cases, treatment still requires surgery even for initial stages [5]. Nonetheless, since it is proven that this resection technique is equally effective and potentially safer than surgery in the treatment of early GI cancers, ESD is progressively gaining more attention by Western endoscopists [5-9].

Our previous study in 2010, focusing on how ESD was being established in Europe for treating gastric lesions, suggested that this technique was performed at few centers, with most endoscopists performing a low number of procedures [10]. It also suggested that many patients could be endoscopically treated with comparable en bloc and $\mathrm{R} 0$ resection rates to the Eastern ones at the expense of slightly higher number of adverse events [10].

A growing number of Western series have been published since then and they seem to report similar results compared to the Eastern ones, apart from colorectal ESD [5].

The aim of this study was to evaluate the current implementation of ESD in Western countries, 8 years after our previous study.

\section{Methods and Participants}

Study Design and Selection of Participants

A MedLine search (through PubMed) was performed to identify published articles related to ESD using the following query: "endoscopic mucosal resection" (Title) OR "EMR" (Title) OR "endoscopic submucosal dissection" (Title) OR "ESD” (Title) AND (“2005/01/01” [PDAT]: “2017/07/03” [PDAT]).

The authors of the 2,943 retrieved articles were identified. After excluding Eastern authors, 279 papers were selected and the corresponding author was contacted by E-Mail and asked to answer a survey built using Google's Form (platform by Google USA). In case of non-response, 2 additional invitations were sent in a 3-month period. Participants were asked to fill it as close as possible to their own clinical/their department's practice. All responses were anonymous.

The answers of 58 western endoscopists whose research, published between 2005 and 2017, was related to EMR or submucosal dissection were selected to this cross-sectional study (Fig. 1).

\section{Survey Characterization}

The survey (Appendix 1) was designed to evaluate the use of ESD technique in 3 different main GI sectors (esophagus, stomach, colon, and rectum) and included 5 main groups of questions:

(a) General data - assessed whether participants were performing ESD or not and, if yes, how many cases were they treating with this technique (ever and in the last year, 2016) 


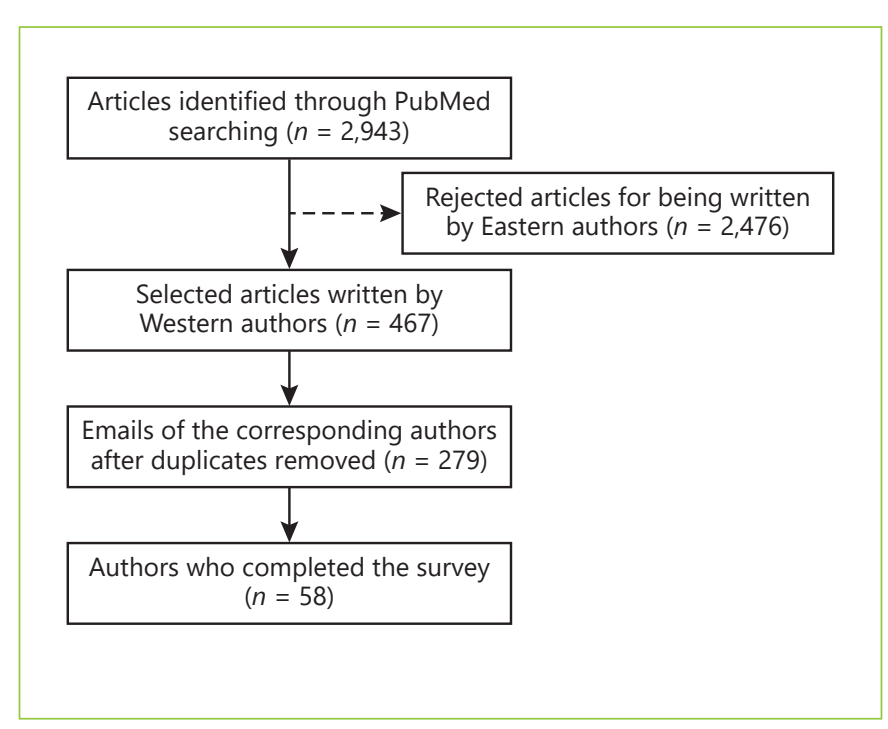

Fig. 1. Fluxogram describing the study design and selection of participants.

(b) Pre-procedure - assessed whether participants were doing radiological or endosonographic evaluation before endoscopic resection and, if yes, what type of examinations did they perform

(c) Procedure - assessed how did the participants characterize the lesions resected (in terms of localization, size, Paris classification [11], histological grade) and how did they perform the ESD technique (instruments, dissection techniques, types of submucosal injection solutions, and strategies for prevention of post-ESD bleeding used)

(d) Post-procedure - assessed whether participants were doing a second-look endoscopy after performing ESD, how did they manage their patients after ESD (acid suppression strategy and oral feeding protocol) and how their outcomes were, regarding en bloc resection and completeness of resection

(e) Follow-up - assessed local and metachronous recurrence rates, the proportion of surgeries due to ESD complications/noncurative disease and the follow-up protocol after endoscopic resection.

It also included 1 question to assess whether participants were performing ESD in the duodenum or not. However, we did not extend the survey as in other GI sectors since ESD is not recommended in duodenum by European guidelines [5].

En bloc resection; R0, R1, and Rx resection; frank and micro perforation, major acute (during the procedure) and delayed bleeding; and local and metachronous recurrence were defined according to European Guidelines [5].

\section{Statistical Analysis}

Data were exported from Google's Form and prepared for statistical analysis. Given the number of answers and the characteristics of the survey, statistical analysis was descriptive. We decided to summarize our variables using absolute and relative frequencies, weighted means or medians.

We used SPSS software version 23 (SPSS Inc., Chicago, IL, USA) to descriptively summarize our data.

How Is ESD for GI Lesions Being Implemented?

\section{Results}

\section{Description of the Participants and Procedures}

Of the 279 contacted physicians, 58 completed the survey $(21 \%)$ and only their responses were included in this study.

While $64 \%$ of the endoscopists' answers reflected their own experience, $36 \%$ reproduced their department's dayto-day practice. Table 1 summarizes the main results concerning participants, resected lesions, outcomes, complications, and follow-up. Figure 2 shows the nationality of the physicians who answered the online survey.

Of the 58 participants, $50(86 \%)$ reported that they performed ESD at least in $1 \mathrm{GI}$ location. Thirty endoscopists performed ESD in the esophagus (52\%), 45 in the stomach (78\%), 36 in the colon and rectum (62\%). Only 6 participants performed ESD in the duodenum (10\%).

The median number of lesions ever resected by each endoscopist was 25 in the esophagus (IQR 2-71), 25 in the stomach (IQR 11-52), and 140 in the colon and rectum (IQR 12-217). Figure 3 shows the median number of ESD procedures per country, in 2016, in each of the GI analyzed segments.

\section{Description of the Resected Lesions and Outcomes \\ Esophagus}

The median minimum diameter of the resected tumors was $12 \mathrm{~mm}$ (IQR 10-17.5) and the median maximum was $70 \mathrm{~mm}$ (IQR 40-100).

Concerning the histological analysis of the esophageal resected lesions, 58\% were classified as Barrett's esophagus-associated lesions and $42 \%$ as squamous cell lesions.

In both types of esophageal carcinomas - Barrett's esophagus-associated adenocarcinoma (AC) and squamous cell cancer - the majority of the lesions were classified as intramucosal carcinomas (53 and 65\%, respectively), followed by intra-epithelial neoplasias (3 and $2 \%$ were classified as low-grade dysplasia, respectively; 22 and $17 \%$ were classified as high-grade dysplasia, respectively).

Altogether, $69 \%$ of the lesions treated with ESD technique were approached as curative cases, with $12 \%$ of patients being submitted to additional treatment (surgery, chemotherapy, and/or radiotherapy) after ESD.

\section{Stomach}

The median minimum and maximum diameter of resected lesions was $10 \mathrm{~mm}$ (IQR 10-15) and $60 \mathrm{~mm}$ (IQR 41.25-80), respectively.

At post-resection histology, lesions were more frequently classified as intramucosal ACs (47\%), followed by 


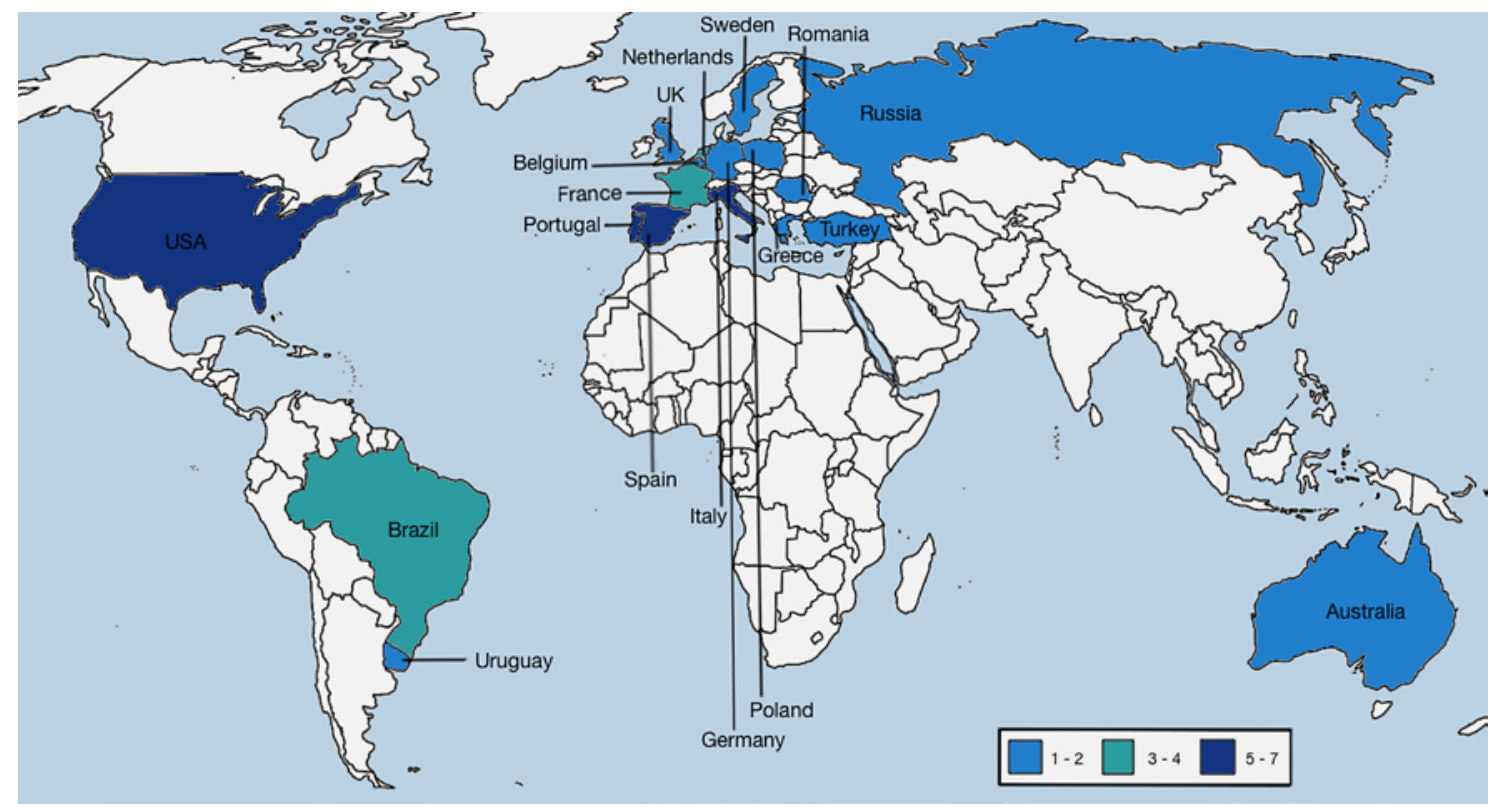

Fig. 2. Nationality of the endoscopists who replied to the online survey. Number of responses per country.

intraepithelial neoplasias (26\% high-grade dysplasia and $10 \%$ low-grade dysplasia).

The resection was considered curative in $70 \%$ of the lesions. However, in $24 \%$ of the cases, patients were submitted to surgery despite ESD due to non-curative resection.

\section{Colon and Rectum}

In this GI domain, lesions measured between $15 \mathrm{~mm}$ (IQR 10-20) and $70 \mathrm{~mm}$ (IQR 6-270).

In the colon and rectum, intraepithelial neoplasias were more common than intramucosal ACs (59 vs. 25\%, respectively). Low-grade dysplasia was found in $25 \%$ of the cases, while $34 \%$ presented with high-grade dysplasia.

ESD technique managed to be curative in $67 \%$ of the lesions. In $11 \%$ of the cases, patients were submitted to surgery due to non-curative resection.

\section{Description of ESD Technique}

Table 2 summarizes the main results concerning ESD technique.

Saline with methylene blue was the preferred submucosal injection in every location. Dual knife was the most used knife in incision and in circumferential/ mucosal dissection $(>34 \%)$ in every location, followed by Flush and Hybrid-knife.

After gastric ESD, the most used acid suppression strategy was PPI perfusion during $48 \mathrm{~h}$, switched to oral intake during 2-8 weeks (53\%). In the absence of compli- cations, oral feeding started more frequently 1 day after ESD, in every location (58\% in esophageal ESD; $66 \%$ in stomach ESD; $60 \%$ in colorectal ESD). In colon and rectum, the majority of the physicians did not prescribe antibiotics (71\%).

\section{Discussion}

To our knowledge this is the first study evaluating ESD implementation in other GI sectors aside from the stomach, in the West. This study suggests that not only the total number of physicians who perform ESD is increasing in Western countries, but also that Western endoscopists are achieving similar results to those in the East, both in terms of efficacy and safety in the treatment of early GI neoplastic lesions.

This study has some limitations. On the one hand, our study is based only on reports of endoscopists who write and publish papers. These physicians are more motivated and may have better results. Additionally, since a part of all ESDs (performed by physicians who were not contacted) were not included, a selection bias might be present. On the other hand, we cannot exclude the possibility of having Eastern endoscopists working in the Western countries. Furthermore, since each endoscopist declares his own/his departments' outcomes and we also do not know how many centers/endoscopists have their per- 
Table 1. Description of participants, resected lesions, outcomes, complications, and follow-up

\begin{tabular}{|c|c|c|c|}
\hline & Esophagus & Stomach & $\begin{array}{l}\text { Colon and } \\
\text { rectum }\end{array}$ \\
\hline \multicolumn{4}{|l|}{ Experience reported, $n(\%)$} \\
\hline Their own & $51(19)$ & $78(29)$ & $62(23)$ \\
\hline Unit experience & $52(11)$ & $76(16)$ & $62(13)$ \\
\hline \multicolumn{4}{|l|}{ Number of cases treated by ESD in 2016 , median (IQR) } \\
\hline Per endoscopist & $7(1-21)$ & $6(4-16)$ & $28(5-63)$ \\
\hline Per center & $10(5-50)$ & $19(8-39)$ & $37(14-70)$ \\
\hline \multicolumn{4}{|l|}{ Number of cases ever treated by ESD (IQR) } \\
\hline Per endoscopist & $25(2-71)$ & $25(11-52)$ & $140(12-217)$ \\
\hline Per center & $34(15-300)$ & $98(38-190)$ & $170(40-340)$ \\
\hline Cases scheduled for ESD in which ESD was performed, \% & 92 & 90 & 82 \\
\hline \multicolumn{4}{|l|}{ Location, $\%$} \\
\hline Cardia & - & 13 & - \\
\hline Fundus & - & 4 & - \\
\hline Gastric body & - & 29 & - \\
\hline Incisura & - & 19 & - \\
\hline Antrum & - & 35 & - \\
\hline Rectum & - & - & 44 \\
\hline Sigmoid/descending colon & - & - & 21 \\
\hline Transverse colon & - & - & 11 \\
\hline Ascending colon & - & - & 25 \\
\hline Cases $>20 \mathrm{~mm}, \%$ & 71 & 65 & 92 \\
\hline \multicolumn{4}{|l|}{ Paris classification, \% } \\
\hline I & 16 & 19 & 24 \\
\hline II & 82 & 75 & 65 \\
\hline III & 0 & 4 & 4 \\
\hline Scar (local recurrence) & 1 & 2 & 7 \\
\hline \multicolumn{4}{|l|}{ Histological diagnosis, $\%$} \\
\hline LGIN/HGIN & & 36 & 59 \\
\hline $\mathrm{AC}$ & 25 & & \\
\hline SCC & 19 & & \\
\hline Intramucosal carcinoma & & 47 & 25 \\
\hline $\mathrm{AC}$ & 53 & & \\
\hline SCC & 65 & & \\
\hline Submucosal invasion & & 17 & 16 \\
\hline $\mathrm{AC}$ & 22 & & \\
\hline SCC & 16 & & \\
\hline \multicolumn{4}{|l|}{ Short-term outcomes, \% } \\
\hline En bloc resection & 97 & 95 & 84 \\
\hline $\mathrm{R} 0$ resection & 88 & 91 & 81 \\
\hline R1 resection & 9 & 5 & 10 \\
\hline $\mathrm{Rx}$ resection & 3 & 4 & 9 \\
\hline Curative cases & 69 & 70 & 67 \\
\hline \multicolumn{4}{|l|}{ Complications, \% } \\
\hline Frank perforation & 1.7 & 1.2 & 4.3 \\
\hline Micro perforation & 1.5 & 0.8 & 2.3 \\
\hline Major acute bleeding during procedure & 0.5 & 0.5 & 1.8 \\
\hline Delayed bleeding & 2.8 & 4.6 & 5.2 \\
\hline Submitted to surgery due to ESD complications & 0.5 & 0.3 & 1.7 \\
\hline \multicolumn{4}{|l|}{ Follow-up, \% } \\
\hline Local recurrence & 2.4 & 1.6 & 2.4 \\
\hline Metachronous recurrence & 11.3 & 8.4 & 10.2 \\
\hline
\end{tabular}

ESD, endoscopic submucosal dissection; LGIN, low grade intraepithelial neoplasia; HGIN, high grade intraepithelial neoplasia; AC, adenocarcinoma; SCC, squamous cell cancer. 
Fig. 3. Median number of ESD procedures per country, in 2016, in each of the GI analyzed segments (I esophagus; II - stomach; III - colon and rectum). Number of ESD procedures per country, in 2016.
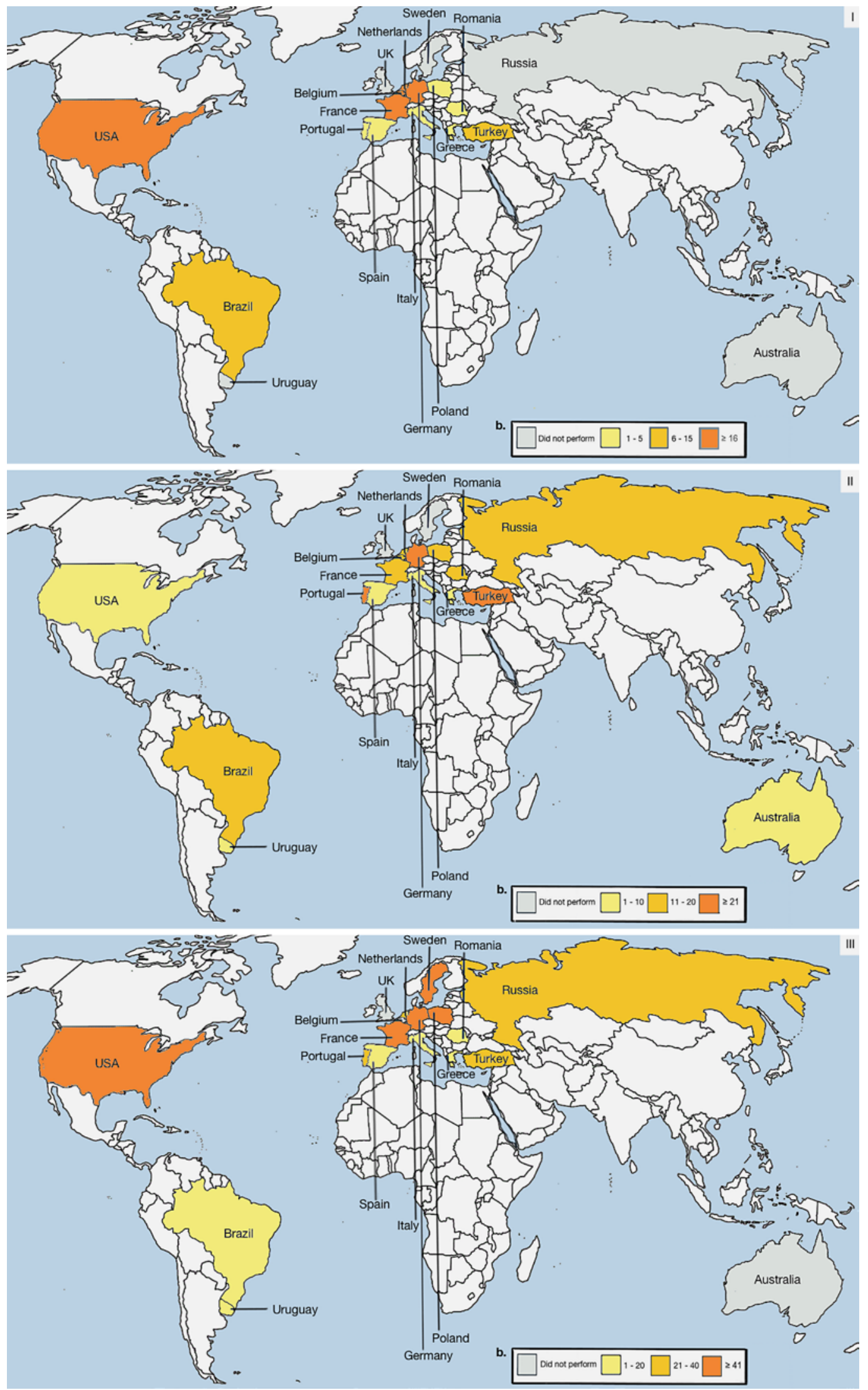
Table 2. Description of ESD technique

Esophagus Stomach

Performed exams before ESD, $n(\%)$

None

CT scan

EUS

Both

Preferred ESD technique, $n$ (\%)

Total circumference before submucosal dissection

Partial circumference before submucosal dissection

Submucosal tunneling

Other

Mostly used knife, $n$ (\%)

Needle knife

INC

$\mathrm{CD} / \mathrm{MD}$

Flex knife

INC

$\mathrm{CD} / \mathrm{MD}$

Hook knife

INC

$\mathrm{CD} / \mathrm{MD}$

Flush knife

INC

$\mathrm{CD} / \mathrm{MD}$

Hybrid knife

INC

$\mathrm{CD} / \mathrm{MD}$

Dual knife

INC

$\mathrm{CD} / \mathrm{MD}$

IT knife

INC

$\mathrm{CD} / \mathrm{MD}$

IT 2 knife

INC

$\mathrm{CD} / \mathrm{MD}$

Other

$$
\text { INC }
$$

$\mathrm{CD} / \mathrm{MD}$

Routinely used strategies to prevent post-ESD hemorrhage, $n$ (\%)

Coagulation of visible vessels with ESD-knife

Coagulation of visible vessels with hemostatic forceps

Clipping of visible vessels

Other

Second-look endoscopies, $n(\%)$

Performed exams in cases of curative criteria, $n(\%)$

None

Chest CT

Abdominal CT

Pelvic CT

PET scan

Endoscopic ultrasound

$\begin{array}{lrr}28(8) & 57(25) & 77(27) \\ 10(3) & 5(2) & 9(3) \\ 28(8) & 16(7) & 9(3) \\ 35(10) & 23(10) & 6(2) \\ & & \\ 21(6) & 48(21) & 11(4) \\ 41(12) & 48(21) & 77(27) \\ 28(8) & 2(1) & 6(2) \\ 10(3) & 2(1) & 6(2)\end{array}$

$0(0) \quad 11(5) \quad 11(4)$

$0(0) \quad 0(0) \quad 3(1)$

$0(0) \quad 0(0) \quad 0(0)$

$0(0) \quad 0(0) \quad 0(0)$

$4(1) \quad 5(2) \quad 6(2)$

$3(1) \quad 5(2) \quad 6(2)$

$26(7) \quad 23(10) \quad 20(7)$

$28(8) \quad 18(8) \quad 23(8)$

$11(3) \quad 18(8) \quad 14(5)$

$10(3) \quad 18(8) \quad 17(6)$

$52(14) \quad 36(16) \quad 46(16)$

$41(12) \quad 34(15) \quad 37(13)$

$0(0) \quad 0(0) \quad 0(0)$

$3(1) \quad 7(3) \quad 6(2)$

$0(0) \quad 5(2) \quad 0(0)$

$0(0) \quad 16(7) \quad 0(0)$

$7(2) \quad 2(1) \quad 3(1)$

$14(4) \quad 2(1) \quad 9(3)$

$33(14) \quad 33(24) \quad 29(15)$

$54(23) \quad 53(38) \quad 52(27)$

$14(6) \quad 13(9) \quad 17(9)$

$0(0) \quad 1(1) \quad 2(1)$

$10(3) \quad 14(6) \quad 14(5)$

$47(18) \quad 57(32) \quad 68(27)$

$18(7) \quad 7(4) \quad 5(2)$

$13(5) \quad 20(11) \quad 18(7)$

$3(1) \quad 5(3) \quad 5(2)$

$5(2) \quad 2(1) \quad 0(0)$

$13(5) \quad 9(5) \quad 5(2)$

ESD, endoscopic submucosal dissection; INC, incision; CD/MD, circumferential dissection/mucosal dissection. 
Table 3. Comparison between our previous 2010 European survey and our current one, considering European participants only [10]

\begin{tabular}{lcc}
\hline & 2010 & 2018 \\
& {$[10]$} & \\
\hline Response, \% & 12 & 22 \\
Endoscopists who performed gastric ESD, \% & 30 & 93 \\
Median number of cases treated by ESD per endoscopist & & \\
$\quad$ Ever & 11 & 20 \\
$\quad$ During the year prior to start of the survey & 4 & 6 \\
Outcomes, \% & 78 & 94 \\
$\quad$ En bloc & 77 & 89 \\
R0 & 13 & 3 \\
$\quad$ Major complications & & \\
\hline
\end{tabular}

Major complications were perforation or bleeding requiring transfusion or modification of endoscopic procedure.

ESD, endoscopic submucosal dissection.

formed cases indexed in databases, this study possibly leads to a reporting bias. Moreover, the response rate is low - approximately, only 1 in 5 of the recipient endoscopists completed the survey. All of these limitations can overestimate the true efficacy and safety of ESD technique in the West. Nevertheless, all of them are inherent to the study design and our participation rate is even higher than most survey studies.

In our previous European survey performed in 2010, $30 \%$ of the endoscopists reported that they performed gastric ESD. In 2018, considering European participants only, 93\% reported that they performed ESD in the stomach [10]. Table 3 compares the main results of both studies.

Some particularities should be mentioned about this study. First, this new survey was designed to evaluate the implementation of ESD technique not only in the stomach, but also in others GI sectors, namely the esophagus and the colon and rectum. Second, it includes more Western countries apart from European ones, which enables a more global and complete perspective of the ESD's dissemination. Third, we obtained a higher response rate in this study, which increased from $12 \%$ (in the previous one) to $21 \%$ (22\%, considering European participants only). Although it is still a low percentage, as mentioned before, it was higher than expected. This increase may be partially explained by the current importance of this theme around Western endoscopy community.

In the esophagus, approximately $60 \%$ of the lesions were classified as Barrett's esophagus-associated lesions and $40 \%$ as squamous cell lesions, which is consistent with the higher incidence of Barrett's esophagus in West- ern countries [12]. Since our esophageal ESD outcomes include 2 types of esophageal superficial lesions, we could not compare them to the majority of recent studies, which focus only on Barrett's esophagus-associated neoplasias or only on squamous cell lesions. Nonetheless, considering European guidelines, our results suggest that esophageal ESD is being safely performed with good resection rates [5]. However, given the high number of esophageal ESDs, ESD is probablybeing performed for some Barrett's lesions that could be treated by EMR. As a matter of fact, a recent European randomized controlled trial, consistent with 2015 European guidelines, suggests that ESD does not seem to have any clinical advantage, compared to EMR, for excision of the majority of visible early Barrett's esophagus lesions $[5,13]$.

In the stomach, our results suggest that ESD is being safely performed with good resection rates too. These results are better than our previous results (Table 3 ) and are consistent with a systematic review with meta-analysis published in 2016 related to gastric ESD [14]. Interestingly, gastric ESD only managed to be curative in $70 \%$ of the lesions, which is lower than what was reported by the meta-analysis mentioned above ( $86 \%$ with a $95 \%$ CI $83-$ 89\%) [14]. Probably, since en-bloc and R0 rates are similar to western series, this means that Western endoscopists are resecting some advanced gastric lesions already with a high risk of deep submucosal invasion, and probably patient selection could be improved $[15,16]$.

In colon and rectum, although ESD is performed by a lower percentage of endoscopists compared to the stomach, the median number of cases treated by this technique is higher. In fact, in absolute terms, colorectal ESD is associated with the highest volume of cases per endoscopist/per center. This may be explained by the fact that the incidence of colorectal cancer is the highest of all GI neoplasms [12] and that the classic indication of early gastric lesions in the East are not frequently observed in most Western countries.

In this study, colorectal ESD had the lowest resection rate and the highest adverse event rate of the 3 GI sectors. Contrary to the stomach, where outcomes were similar to recent data, in the colon and rectum, outcomes were consistently lower. Only R0 resection rate was comparable to a recent meta-analysis published in 2016 [17]. Moreover, contrary to the upper GI, intraepithelial neoplasias (dysplasia) were more common than carcinomas (approximately $60 \%$ non-invasive/benign neoplasias versus $40 \%$ invasive/malign neoplasias). This point is very important to discuss as colorectal ESD is being performed more often than necessary. 
Actually, colorectal ESD is controversial. Part of the scientific community advocates that ESD should be the standard number-one option to treat all large colorectal lesions, since it is associated with superior en bloc and R0 resection rates and lower recurrence rates, compared to EMR [18-24]. On the contrary, some argue that it is not cost-effective to treat all these lesions with ESD, as it is more time-consuming, has a higher adverse event rate, is technically more difficult and, more importantly, the majority of the lesions can be effectively and more safely removed by EMR [25-28]. Until the present moment, there are no randomized controlled trials comparing ESD with EMR. Therefore, considering that these techniques are currently used for different indications, a comparison between them, based on retrospective studies, is a difficult task due to selection bias [29].

Regarding safety profile, the general outcome improvement is consistent with a national survey conducted in France, during 2017. This study showed that there has been an improvement over time of en bloc resection rate, which has increased from 77.1 to $91.7 \%(p<0.001)$, and a decrease over time in complication rate, which went from 29.2 to $14.1 \%(p<0.001)$, since the implementation of ESD technique in the country [30]. Delayed bleeding remains one of the main complications of ESD. Prophylactic coagulation of visible vessels and use of an acid suppression strategy (proton pump inhibitors primarily) are important to reduce the risk of delayed bleeding $[31,32]$. Nonetheless, even with these strategies, evidence suggests that there is still approximately $5 \%$ delayed bleeding rate associated with gastric ESD, for example, consistent with our rates [31-33]. Physicians are opting now to perform second look endoscopies, which is also consistent with current evidence that suggests that the majority of the patients submitted to ESD might not benefit from second look endoscopy [31-33].

In conclusion, ESD seems to be performed in a safe and effective way by a large number of centers and endoscopists in the Western world. Our results suggest widespread ESD implementation in Western countries, with good rates of efficacy and safety according to European guidelines, with the exception of colorectal ESD that could be used more often than necessary. It is necessary to establish adequate training programs for Western trainees, since a traditional Eastern stepwise mentor/apprentice approach may not always be suitable [5]. In addition, standardization of the ESD technique and establishment of criteria for its use are essential, to accomplish similar results to Eastern series.

\section{Statement of Ethics}

The authors have no ethical conflicts to disclose.

\section{Disclosure Statement}

The authors declare that there is no conflict of interest regarding the publication of this paper.

Appendix

Final survey

0.1 E-Mail

0.2 Does your answer reflect your own practice or your department's?

\section{Stomach}

Stomach ESD: general data

1. Do you perform ESD in the stomach?

1.1. Which year was gastric ESD introduced in your practice/department?

1.2. How many cases of superficial gastric lesions were treated by ESD last year (2016)?

1.3. How many cases of superficial gastric lesions were treated by ESD ever?

Stomach ESD: pre-procedure

1.4. Which exams do you perform before ESD?

(a) I don't perform either radiologic or endosonographic exams before ESD

(b) CT scan

(c) EUS

(d) Both

How Is ESD for GI Lesions Being Implemented?
GE Port J Gastroenterol 2020;27:1-17 DOI: $10.1159 / 000501404$ 
1.5. What was the proportion of cases (\%) scheduled for ESD in which ESD was performed (feasibility)?

1.6. Which of the following techniques is currently your preferred, for gastric ESD?

(a) Total circumferential before submucosal dissection

(b) Partial circumferential before submucosal dissection

(c) Submucosal tunneling

(d) Other

1.7. As far as INCISION is concerned, which kind of knife is mostly used?
(a) Needle knife
(b) Flex knife
(c) Hook knife
(d) Flush knife
(e) Hybrid knife
(f) Dual knife
(g) IT knife
(h) IT2 knife
(i) Other

1.8. As far as CIRCUMFERENTIAL DISSECTION/ MUCOSAL DISSECTION is concerned, which kind of knife is mostly used?
(a) Needle knife
(b) Flex knife
(c) Hook knife
(d) Flush knife
(e) Hybrid knife
(f) Dual knife
(g) IT knife
(h) IT2 knife
(i) Other

1.9. Which submucosal injection solution do you usually use (e.g., saline with methylene blue)?

1.10 .

1.10.1. What was the proportion of cases $(\%)$ resected in CARDIA?

1.10.2. What was the proportion of cases (\%) resected in the FUNDUS?

1.10.3. What was the proportion of cases (\%) resected in GASTRIC BODY?

1.10.4. What was the proportion of cases (\%) resected in INCISURA?

1.10.5. What was the proportion of cases (\%) resected in ANTRUM?

1.11.

1.11.1. Please estimate the percentage (\%) of lesion classified as I:

1.11.2. Please estimate the percentage (\%) of lesion classified as II (accept IIc + IIa; etc.):

1.11.3. Please estimate the percentage (\%) of lesion classified as III:

1.11.4. Please estimate the percentage (\%) of lesion classified as a scar:

1.12 .

1.12.1. What was the MINIMUM diameter of lesions resected?

1.12.2. What was the MAXIMUM diameter of lesions resected?

1.12.3. What was the proportion of cases $>20 \mathrm{~mm}(\%)$ ?

1.13.1. What was the proportion of cases (\%) with EN BLOC RESECTION (tumor was resected in one piece)?

1.14. What strategies do you routinely use for prevention of post-ESD hemorrhage? (possible to select $>1$ )

(a) Coagulation of visible vessels with ESD-knife

(b) Coagulation of visible vessels with hemostatic forceps

(c) Clipping of visible vessels

(d) Other 
Stomach ESD: post-procedure

1.15. Do you routinely perform second-look endoscopy?

1.15.1. If yes, how many hours after ESD?

1.16.

1.16.1 What is the acid suppression strategy after ESD? (free text)

1.16.2. In the absence of complications, how many days after ESD does oral feeding start?

1.16.3. What is the routine period of inpatient surveillance after ESD (in days)?

1.16.4. What was the proportion of cases (\%) with frank perforation (visible perforation during procedure)?

1.16.5. What was the proportion of cases (\%) with micro perforation (free air on X-ray/CT without visible perforation during procedure)?

1.16.6. What was the proportion of cases (\%) with major acute bleeding during procedure (massive bleeding requiring transfusing or modification of endoscopic procedure)?

1.16.7. What was the proportion of cases (\%) with delayed bleeding (decrease of $\mathrm{Hb} 2 \mathrm{~g} / \mathrm{dL}$, transfusion or endoscopic/ surgical procedure because hematemesis or melena in the postoperative period)?

1.16.8. What was the proportion of cases (\%) that were submitted to surgery because of complications?

1.16.9. If others, please specify (description and number):

1.17 .

1.17.1. Regarding the post resection histology of the lesion, what was the proportion of cases (\%) with low grade intraepithelial neoplasia?

1.17.2. Regarding the post resection histology of the lesion, what was the proportion of cases (\%) with high grade intraepithelial neoplasia?

1.17.3. Regarding the post resection histology of the lesion, what was the proportion of cases (\%) with intramucosal adenocarcinoma?

1.17.4. Regarding the post resection histology of the lesion, what was the proportion of cases (\%) with adenocarcinoma with superficial submucosal invasion (pT1b sm1)?

1.17.5. Regarding the post resection histology of the lesion, what was the proportion of cases (\%) with adenocarcinoma with deep submucosal invasion (pTlb > sm1)?

1.18 .

1.18.1. Regarding the completeness of resection/histological assessment, what was the proportion of cases (\%) with R0 (lateral and vertical margins were free of tumor)?

1.18.2. Regarding the completeness of resection/histological assessment, what was the proportion of cases (\%) with R1 (tumor extends into margins)?

1.18.3. Regarding the completeness of resection/histological assessment, what was the proportion of cases (\%) with $\mathrm{Rx}$ (not possible to define - coagulation effects/piecemeal resection)?

1.18.4. According to ESGE Endoscopic Submucosal Dissection guidelines, what is the proportion (\%) of non-curative cases?

Stomach ESD: follow-up

1.19 .

1.19.1. Which exams do you perform in cases of curative criteria? (select more than one if applicable)

(a) I don't perform radiological exams

(b) Chest CT

(c) Abdominal CT

(d) Pelvic CT

(e) PET scan

(f) Endoscopic ultrasound

1.19.2. What is the follow-up interval between radiological exams (in years)?

1.20 .

1.20.1. At follow-up, what is the proportion of cases (\%) with local recurrence (neoplastic lesion at the same site after procedure)?

1.20.2. At follow-up, what is the proportion of cases (\%) with metachronous recurrence (neoplastic lesion at a different site)?

Stomach ESD: complications

1.21.

1.21.1. How many patients were submitted to surgery despite ESD, for complications?

1.12.2. How many patients were submitted to surgery despite ESD due to non-curative resection?

How Is ESD for GI Lesions Being

Implemented?
GE Port J Gastroenterol 2020;27:1-17

DOI: $10.1159 / 000501404$ 
Duodenum

Duodenum ESD: general data

2. Do you perform ESD in duodenum?

\section{Esophagus}

Esophagus ESD: general data

3. Do you perform ESD in esophagus?

3.1. Which year was esophageal ESD introduced in your practice/department?

3.2. How many cases of superficial esophageal lesions were treated by ESD last year (2016)?

3.3. How many cases of superficial esophageal lesions were treated by ESD ever?

Esophagusm ESD: pre-procedure

3.4. Which exams do you perform before ESD?

(a) I don't perform either radiologic or endosonographic exams before ESD

(b) CT scan

(c) EUS

(d) Both

Esophagus: procedure

3.5. What was the proportion of cases (\%) scheduled for ESD in which ESD was performed (feasibility)?

3.6. Which of the following techniques is currently your preferred, for esophageal ESD?
(a) Total circumferential before submucosal dissection
(b) Partial circumferential before submucosal dissection
(c) Submucosal tunneling
(d) Other

3.7. As far as INCISION is concerned, which kind of knife is mostly used?
(a) Needle knife
(b) Flex knife
(c) Hook knife
(d) Flush knife
(e) Hybrid knife
(f) Dual knife
(g) IT knife
(h) IT2 knife
(i) Other

3.8. As far as CIRCUMFERENTIAL DISSECTION/ SUBMUCOSAL DISSECTION is concerned, which kind of knife is mostly used?
(a) Needle knife
(b) Flex knife
(c) Hook knife
(d) Flush knife
(e) Hybrid knife
(f) Dual knife
(g) IT knife
(h) IT2 knife
(i) Other

3.9. Which submucosal injection solution do you usually use (e.g., saline with methylene blue)?

3.10 .

3.10.1. What was the proportion of cases (\%) resected with squamous cell lesion?

3.10.2. What was the proportion of cases (\%) resected with Barrett lesion?

3.11 .

3.11.1. Please estimate the percentage (\%) of lesion classified as I:

3.11.2. Please estimate the percentage (\%) of lesion classified as II (accept IIc + IIa; etc.):

3.11.3. Please estimate the percentage (\%) of lesion classified as III:

3.11.4. Please estimate the percentage (\%) of lesion classified as a scar: 
3.12 .

3.12.1. What was the MINIMUM diameter of lesions resected?

3.12.2. What was the MAXIMUM diameter of lesions resected?

3.12.3. What was the proportion of cases $>20 \mathrm{~mm}(\%)$ ?

3.13 .

3.13.1. What was the proportion of cases (\%) with EN BLOC RESECTION (tumor was resected in one piece)?

3.14. What strategies do your routinely use for prevention of post-ESD hemorrhage? (possible to select more than one)

(a) Coagulation of visible vessels with ESD-knife

(b) Coagulation of visible vessels with hemostatic forceps

(c) Clipping of visible vessels

(d) Other

Esophagus: post-procedure

3.15. Do you routinely perform second-look endoscopy?

3.15.1. If yes, how many hours after ESD?

3.16 .

3.16.1. What is the acid suppression strategy after ESD? (free text)

3.16.2. In the absence of complications, how many days after ESD does oral feeding start?

3.16.3. What is the routine period of inpatient surveillance after ESD (in days)?

3.17 .

3.17.1. What was the proportion of cases (\%) with frank perforation (visible perforation during procedure)?

3.17.2. What was the proportion of cases (\%) with micro perforation (free air on X-ray/CT without visible perforation during procedure)?

3.17.3. What was the proportion of cases (\%) with major acute bleeding during procedure (massive bleeding requiring transfusing or modification of endoscopic procedure)?

3.17.4. What was the proportion of cases (\%) with delayed bleeding (decrease of $\mathrm{Hb} 2 \mathrm{~g} / \mathrm{dL}$, transfusion or endoscopic/ surgical procedure because hematemesis or melena in the postoperative period)?

3.17.5. What was the proportion of cases (\%) that were submitted to surgery because of complications?

3.17.6. If others, please specify (description and number):

3.18 .

Barret lesion

3.18.1. Regarding the post resection histology of the lesion, what was the proportion of cases (\%) with low grade intraepithelial neoplasia?

3.18.2. Regarding the post resection histology of the lesion, what was the proportion of cases (\%) with high grade intraepithelial neoplasia?

3.18.3. Regarding the post resection histology of the lesion, what was the proportion of cases (\%) with intramucosal adenocarcinoma?

3.18.4. Regarding the post resection histology of the lesion, what was the proportion of cases (\%) with adenocarcinoma with superficial submucosal invasion (pT1b sm1)?

3.18.5. Regarding the post resection histology of the lesion, what was the proportion of cases (\%) with adenocarcinoma with deep submucosal invasion ( $\mathrm{pT} 1 \mathrm{~b}>\mathrm{sm} 1)$ ?

Squamous cell lesion

3.18.6. Regarding the post resection histology of the lesion, what was the proportion of cases (\%) with low grade squamous dysplasia?

3.18.7. Regarding the post resection histology of the lesion, what was the proportion of cases (\%) with high grade squamous dysplasia?

3.18.8. Regarding the post resection histology of the lesion, what was the proportion of cases (\%) with intramucosal squamous cell carcinoma?

3.18.9. Regarding the post resection histology of the lesion, what was the proportion of cases (\%) with submucosal squamous cell carcinoma? 
3.19 .

3.19.1. Regarding the completeness of resection/histological assessment, what was the proportion of cases (\%) with R0 (lateral and vertical margins were free of tumor)?

3.19.2. Regarding the completeness of resection/histological assessment, what was the proportion of cases (\%) with R1 (tumor extends into margins)?

3.19.3. Regarding the completeness of resection/histological assessment, what was the proportion of cases (\%) with $\mathrm{Rx}$ (not possible to define - coagulation effects/piecemeal resection)?

3.19.4. According to ESGE Endoscopic Submucosal Dissection guidelines, what is the proportion (\%) of non-curative cases?

Esophagus ESD: follow-up

3.20 .

3.20.1. Which exams do you perform in cases of curative criteria? (select more than one if applicable)

(a) I don't perform radiological exams

(b) Chest CT

(c) Abdominal CT

(d) Pelvic CT

(e) PET scan

(f) Endoscopic ultrasound

3.20.2. What is the follow-up interval between radiological exams (in years)?

3.21 .

3.21.1. At follow-up, what is the proportion of cases (\%) with local recurrence (neoplastic lesion at the same site after procedure)?

3.21.2. At follow-up, what is the proportion of cases (\%) with metachronous recurrence (neoplastic lesion at a different site)?

3.22. How many patients were submitted to additional treatment (surgery, chemotherapy, radiotherapy) despite ESD?

\section{Colon and rectum}

Colon and rectum ESD: general data

4. Do you perform ESD in colon and rectum?

4.1. Which year was colon and rectum ESD introduced in your practice/department?

4.2. How many cases of superficial colon and rectum lesions were treated by ESD last year (2016)?

4.3. How many cases of superficial colon and rectum lesions were treated by ESD ever?

Colon and rectum ESD: pre-procedure

4.4. Which exams do you perform before ESD?

(a) I don't perform either radiological or endosonographic exams before ESD

(b) CT scan

(c) EUS

(d) Both

Colon and rectum ESD: procedure

4.5. What was the proportion of cases (\%) scheduled for ESD in which ESD was performed (feasibility)?

4.6. Which of the following techniques is currently preferred, for colon-rectum ESD?

(a) Total circumferential before submucosal dissection

(b) Partial circumferential before submucosal dissection

(c) Submucosal tunneling

(d) Other

4.7. As far as INCISION is concerned, which kind of knife is mostly used?

(a) Needle knife

(b) Flex knife

(c) Hook knife

(d) Flush knife

(e) Hybrid knife

(f) Dual knife

(g) IT knife

(h) IT2 knife

(i) Other 
4.8. As far as CIRCUMFERENTIAL DISSECTION/ SUBMUCOSAL DISSECTION is concerned, which kind of knife is mostly used?
(a) Needle knife
(b) Flex knife
(c) Hook knife
(d) Flush knife
(e) Hybrid knife
(f) Dual knife
(g) IT knife
(h) IT2 knife
(i) Other

4.9. Which submucosal injection solution do you usually use (e.g., saline with methylene blue)?

4.10.

4.10.1. What was the proportion of cases (\%) resected in RECTUM?

4.10.2. What was the proportion of cases (\%) resected in SIGMOID/ DESCENDING COLON?

4.10.3. What was the proportion of cases (\%) resected in TRANSVERSE COLON?

4.10.4. What was the proportion of cases (\%) resected in ASCENDING COLON?

4.11 .

4.11.1. Please estimate the percentage (\%) of lesion classified as I:

4.11.2. Please estimate the percentage (\%) of lesion classified as II (accept IIc + IIa; etc.):

4.11.3. Please estimate the percentage (\%) of lesion classified as III:

4.11.4. Please estimate the percentage (\%) of lesion classified as a scar:

4.12 .

4.12.1. What was the MINIMUM diameter of lesions resected?

4.12.2. What was the MAXIMUM diameter of lesions resected?

4.12.3. What was the proportion of cases $>20 \mathrm{~mm}(\%)$ ?

4.13 .

4.13.1. What was the proportion of cases (\%) with EN BLOC RESECTION (tumor was resected in one piece)?

4.14. What strategies do your routinely use for prevention of post-ESD hemorrhage? (possible to select $>1$ )

(a) Coagulation of visible vessels with ESD-knife

(b) Coagulation of visible vessels with hemostatic forceps

(c) Clipping of visible vessels

(d) Other

Colon and rectum: post-procedure

4.15. Do you routinely perform second-look endoscopy?

4.15.1. If yes, how many hours after ESD?

4.16.

4.16.1. Do you prescribe antibiotics after ESD?

4.16.2. In the absence of complications, how many days after ESD does oral feeding start?

4.16.3. What is the routine period of inpatient surveillance after ESD (in days)?

4.17.

4.17.1. What was the proportion of cases (\%) with frank perforation (visible perforation during procedure)?

4.17.2. What was the proportion of cases (\%) with micro perforation (free air on X-ray/CT without visible perforation during procedure)?

4.17.3. What was the proportion of cases (\%) with major acute bleeding during procedure (massive bleeding requiring transfusing or modification of endoscopic procedure)?

4.17.4. What was the proportion of cases (\%) with delayed bleeding (decrease of $\mathrm{Hb} 2 \mathrm{~g} / \mathrm{dL}$, transfusion or endoscopic/ surgical procedure because hematochezia in the postoperative period)?

4.17.5. What was the proportion of cases (\%) that were submitted to surgery because of complications?

4.17.6. If others, please specify (description and number)

How Is ESD for GI Lesions Being

Implemented?
GE Port J Gastroenterol 2020;27:1-17

DOI: $10.1159 / 000501404$ 
4.18 .

4.18.1. Regarding the post resection histology of the lesion, what was the proportion of cases (\%) with low grade intraepithelial neoplasia?

4.18.2. Regarding the post resection histology of the lesion, what was the proportion of cases (\%) with high grade intraepithelial neoplasia?

4.18.3. Regarding the post resection histology of the lesion, what was the proportion of cases (\%) with intramucosal adenocarcinoma?

4.18.4. Regarding the post resection histology of the lesion, what was the proportion of cases (\%) with adenocarcinoma with superficial submucosal invasion (pT1b sm1)?

4.18.5. Regarding the post resection histology of the lesion, what was the proportion of cases (\%) with adenocarcinoma with deep submucosal invasion $(\mathrm{pT} 1 \mathrm{~b}>\mathrm{sm} 1)$ ?

4.19 .

4.19.1. Regarding the completeness of resection/histological assessment, what was the proportion of cases (\%) with R0 (lateral and vertical margins were free of tumor)?

4.19.2. Regarding the completeness of resection/histological assessment, what was the proportion of cases (\%) with R1 (tumor extend into margins)?

4.19.3. Regarding the completeness of resection/histological assessment, what was the proportion of cases (\%) with $\mathrm{Rx}$ (not possible to define - coagulation effects/piecemeal resection)?

4.19.4. According to ESGE Endoscopic Submucosal Dissection guidelines, what is the proportion (\%) of non curative cases?

Colon and rectum: follow-up

4.20 .

4.20.1. Which exams do you perform in cases of curative criteria? (select more than one if applicable)

(a) I don't perform radiological exams

(b) Chest CT

(c) Abdominal CT

(d) Pelvic CT

(e) PET scan

(f) Endoscopic ultrasound

4.20.2. What is the follow-up interval between radiological exams (in years)?

4.21 .

4.21.1. At follow-up, what is the proportion of cases (\%) with local recurrence (neoplastic lesion at the same site after procedure)?

4.21.2. At follow-up, what is the proportion of cases (\%) with metachronous lesion?

4.22 .

4.22.1. How many patients were submitted to surgery despite ESD, for complications?

4.22.2. How many patients were submitted to surgery despite ESD due to non-curative resection?

\section{References}

1 Gotoda T, Jung HY. Endoscopic resection (endoscopic mucosal resection/ endoscopic submucosal dissection) for early gastric cancer. Dig Endosc. 2013 Mar;25 Suppl 1:55-63.

2 Lang GD, Konda VJ, Siddiqui UD, Koons A, Waxman I. A single-center experience of endoscopic submucosal dissection performed in a Western setting. Dig Dis Sci. 2015 Feb;60(2): 531-6.

3 Białek A, Pertkiewicz J, Karpińska K, Marlicz W, Bielicki D, Starzyńska T. Treatment of large colorectal neoplasms by endoscopic submucosal dissection: a European singlecenter study. Eur J Gastroenterol Hepatol. 2014 Jun;26(6):607-15.
4 Lian J, Chen S, Zhang Y, Qiu F. A meta-analysis of endoscopic submucosal dissection and EMR for early gastric cancer. Gastrointest Endosc. 2012 Oct;76(4):763-70.

5 Pimentel-Nunes P, Dinis-Ribeiro M, Ponchon T, Repici A, Vieth M, De Ceglie A, et al. Endoscopic submucosal dissection: European Society of Gastrointestinal Endoscopy (ESGE) Guideline. Endoscopy. 2015 Sep; 47(9):829-54

6 Catalano F, Trecca A, Rodella L, Lombardo F, Tomezzoli A, Battista S, et al. The modern treatment of early gastric cancer: our experience in an Italian cohort. Surg Endosc. 2009 Jul;23(7):1581-6.
7 Deprez PH, Bergman JJ, Meisner S, Ponchon T, Repici A, Dinis-Ribeiro M, et al. Current practice with endoscopic submucosal dissection in Europe: position statement from a panel of experts. Endoscopy. 2010 Oct;42(10): 853-8.

8 Pimentel-Nunes $\mathrm{P}$, Mourão F, Veloso N, Afonso LP, Jácome M, Moreira-Dias L, et al. Long-term follow-up after endoscopic resection of gastric superficial neoplastic lesions in Portugal. Endoscopy. 2014 Nov;46(11):93340. 
9 Libanio D, Braga V, Ferraz S, Castro R, Lage J, Pita I, et al. Prospective comparative study of endoscopic submucosal dissection and gastrectomy for early neoplastic lesions including patients' perspectives. Endoscopy. 2019 Jan;51(1):30-39.

10 Ribeiro-Mourão F, Pimentel-Nunes P, DinisRibeiro M. Endoscopic submucosal dissection for gastric lesions: results of an European inquiry. Endoscopy. 2010 Oct;42(10):814-9.

11 Participants in the Paris Workshop. The Paris endoscopic classification of superficial neoplastic lesions: esophagus, stomach, and colon: November 30 to December 1, 2002. GastrointestEndosc. 2003 Dec;58(6Suppl):S3-43.

12 Ferlay J, Colombet M, Soerjomataram I, Mathers C, Parkin DM, Piñeros M, et al. Estimating the global cancer incidence and mortality in 2018: GLOBOCAN sources and methods. Int J Cancer. 2019 Apr;144(8): 1941-53.

13 Terheggen G, Horn EM, Vieth M, Gabbert H, Enderle M, Neugebauer A, et al. A randomised trial of endoscopic submucosal dissection versus endoscopic mucosal resection for early Barrett's neoplasia. Gut. 2017 May; 66(5):783-93.

14 Akintoye E, Obaitan I, Muthusamy A, Akanbi O, Olusunmade M, Levine D. Endoscopic submucosal dissection of gastric tumors: A systematic review and meta-analysis. World J Gastrointest Endosc. 2016 Aug;8(15):517-32.

15 Libânio D, Pimentel-Nunes P, Afonso LP, Henrique R, Dinis-Ribeiro M. Long-Term Outcomes of Gastric Endoscopic Submucosal Dissection: Focus on Metachronous and Non-Curative Resection Management. GE Port J Gastroenterol. 2017 Jan;24(1):31-9.

16 Probst A, Schneider A, Schaller T, Anthuber M, Ebigbo A, Messmann H. Endoscopic submucosal dissection for early gastric cancer: are expanded resection criteria safe for Western patients? Endoscopy. 2017 Sep;49(9): 855-65.

17 Akintoye E, Kumar N, Aihara H, Nas H, Thompson CC. Colorectal endoscopic submucosal dissection: a systematic review and meta-analysis. Endosc Int Open. 2016 Oct; 4(10):E1030-44.
18 Arezzo A, Passera R, Marchese N, Galloro G, Manta R, Cirocchi R. Systematic review and meta-analysis of endoscopic submucosal dissection vs endoscopic mucosal resection for colorectal lesions. United European Gastroenterol J. 2016 Feb;4(1):18-29.

19 Backes Y, Moons LM, van Bergeijk JD, Berk L, Ter Borg F, Ter Borg PC, et al. Endoscopic mucosal resection (EMR) versus endoscopic submucosal dissection (ESD) for resection of large distal non-pedunculated colorectal adenomas (MATILDA-trial): rationale and design of a multicenter randomized clinical trial. BMC Gastroenterol. 2016 May;16(1):56.

20 Boda K, Oka S, Tanaka S, Nagata S, Kunihiro $\mathrm{M}$, Kuwai T, et al. Clinical outcomes of endoscopic submucosal dissection for colorectal tumors: a large multicenter retrospective study from the Hiroshima GI Endoscopy Research Group. Gastrointest Endosc. 2018 Mar;87(3):714-22.

21 Chao G, Zhang S, Si J. Comparing endoscopic mucosal resection with endoscopic submucosal dissection: the different endoscopic techniques for colorectal tumors. J Surg Res. 2016 May;202(1):204-15.

22 Chen T, Qin WZ, Yao LQ, Zhong YS, Zhang YQ, Chen WF, et al. Long-term outcomes of endoscopic submucosal dissection for highgrade dysplasia and early-stage carcinoma in the colorectum. Cancer Commun (Lond). 2018 Mar;38(1):3.

23 Chiba H, Tachikawa J, Kurihara D, Ashikari $\mathrm{K}$, Goto T, Takahashi A, et al. Safety and efficacy of simultaneous colorectal ESD for large synchronous colorectal lesions. Endosc Int Open. 2017 Jul;5(7):E595-602.

24 De Ceglie A, Hassan C, Mangiavillano B, Matsuda T, Saito Y, Ridola L, et al. Endoscopic mucosal resection and endoscopic submucosal dissection for colorectal lesions: A systematic review. Crit Rev Oncol Hematol. 2016 Aug;104:138-55.

25 Holmes I, Friedland S. Endoscopic Mucosal Resection versus Endoscopic Submucosal Dissection for Large Polyps: A Western Colonoscopist's View. Clin Endosc. 2016 Sep; 49(5):454-6.
26 Awadie H, Repici A, Bourke MJ. Endoscopic management of large nonpedunculated colorectal polyps: selective treatment algorithms are needed. Endoscopy. 2017 Mar; 49(3):214-6.

27 Fuccio L, Repici A, Hassan C, Ponchon T, Bhandari P, Jover R, et al. Why attempt en bloc resection of non-pedunculated colorectal adenomas? A systematic review of the prevalence of superficial submucosal invasive cancer after endoscopic submucosal dissection. Gut. 2018 Aug;67(8):1464-74.

28 Shigita K, Oka S, Tanaka S, Sumimoto K, Hirano D, Tamaru Y, et al. Long-term outcomes after endoscopic submucosal dissection for superficial colorectal tumors. Gastrointest Endosc. 2017 Mar;85(3):546-53.

29 Kanesaka T, Toth E, Thorlacius H. Selection bias complicates comparisons of endoscopic submucosal dissection vs. endoscopic mucosal resection in the treatment of colorectal neoplasms. Endoscopy. 2017 May;49(5):511.

30 Barret M, Lepilliez V, Coumaros D, Chaussade S, Leblanc S, Ponchon T, et al.; Société Française d'Endoscopie Digestive (SFED). The expansion of endoscopic submucosal dissection in France: A prospective nationwide survey. United European Gastroenterol J. 2017 Feb; 5(1):45-53.

31 Libânio D, Costa MN, Pimentel-Nunes P, Dinis-Ribeiro M. Risk factors for bleeding after gastric endoscopic submucosal dissection: a systematic review and meta-analysis. Gastrointest Endosc. 2016 Oct;84(4):572-86.

32 Kim SJ, Choi CW, Kang DH, Kim HW, Park SB. Second-look endoscopy and factors associated with delayed bleeding after endoscopic submucosal dissection. World J Gastrointest Endosc. $2016 \mathrm{Feb} ; 8(3): 173-9$.

33 Goto O, Fujishiro M, Oda I, Kakushima N, Yamamoto Y, Tsuji Y, et al. A multicenter survey of the management after gastric endoscopic submucosal dissection related to postoperative bleeding. Dig Dis Sci. 2012 Feb; 57(2):435-9.
How Is ESD for GI Lesions Being Implemented?
GE Port J Gastroenterol 2020;27:1-17 DOI: $10.1159 / 000501404$ 